\title{
The relationship between teaching practices and students' achievement in mathematics in Lesotho
}

\author{
Gerrit Stols ${ }^{1} \mathrm{~J}$ eanne Kriek ${ }^{2}$ and Ugorji Iheanachor Ogbonnaya ${ }^{3}$ \\ ${ }^{1}$ Dept. of Science Mathematics and Technology Education, University of Pretoria \\ ${ }^{2}$ Institute for Science and Technology Education, University of South Africa and \\ ${ }^{3}$ National University of Lesotho International School \\ gerrit.stols@up.ac.za; kriekj@unisa.ac.za; ugoh5000@yahoo.com.au
}

\begin{abstract}
Research has found that teaching practices are a critical factor in promoting student achievement in mathematics and may therefore explain a substantial portion of the variance in student learning and achievement. The aim of this study was to assess the relationship between student achievement in mathematics and teachers' teaching practices in the Maseru District in Lesotho, Southern Africa. A self-report instrument - Mathematics Teaching Opinionate Scale (MaTOS) was used to collect data from 40 Form $\mathrm{C}$ (Grade 10) mathematics teachers about their teaching practices. This paper outlines correlations found between specific teaching practices (formal presentation, teacher-guided discussion, group work and homework) and student achievement in mathematics. Possible implications of these correlations are discussed and recommendations for further research are put forward.
\end{abstract}

\section{Background}

The educational situation in Lesotho is similar to that of other developing countries. However, the government of Lesotho wants to broaden access to basic education, including secondary education, in order to meet the target of education for all by 2015 (Ogbonnaya, 2007). Steen (1989) has pointed out that the mathematical sciences have moved from not only being a requirement for future scientists, but are now an essential ingredient in the education of all students. There is a real need, therefore, in Lesotho, to improve student achievement in mathematics. According to statistics from the Examination Council of Lesotho (ECoL), students' performance in mathematics in the Cambridge Overseas School Certificate (COSC) for the past six years has been below 12\% credit (ECOL, 2001; 2005 and 2006). This means that less than $12 \%$ of the candidates were able to score above $50 \%$ in the mathematics examination. The implication of this is that only a few of these students will be admissible to study science and technology careers in the institutions of higher learning in the country, because having a credit in mathematics is a prerequisite for such admissions. Hence there is a need, in Lesotho, to improve student achievement in mathematics.

In Lesotho the Junior Certificate (JC) mathematics curriculum is underpinned by a learnercentred philosophy that emphasises understanding and the application of mathematical concepts as opposed to rote memorisation and the application of formulae (Ministry of Education, 2002). Evidence from research studies has shown that teaching practices are a critical factor in promoting student achievement in mathematics (Peterson, 1998; Stigler \& Hiebert, 1999; Wenglinsky, 2002). If this is the case, then teaching practices may indeed explain a substantial portion of the variance in student learning and achievement. In a study done by Kanyongo, Schreiber and Brown (2007), which focused on determining the factors that influenced mathematical achievement among $6^{\text {th }}$ graders in three sub-Saharan African countries, it was found that the number of livestock owned by the student's family, as well as teachers' content knowledge, had a positive influence on the 
mathematical achievement of learners in Lesotho. This study also found that, in Lesotho, the mothers' education and teachers' teaching experience had no influence on learners' mathematical achievement. Although the study used and tested homework done as one of the variables, this was not considered to be the best choice of variable. The correlation between homework and student achievement in an environment such as Lesotho still needs to be studied empirically. This study therefore looked at amongst others at the influence of homework, as a form of teaching practice, and could therefore contribute to the relationship between teaching practices and students' achievement in mathematics in Lesotho.

\section{Literature review}

Research in developed countries illustrates that a substantial part of the difference in student achievement is attributable to teachers and their teaching practices (Darling-Hammond, 2000; Rice, 2003, Ingvarson et al., 2004). However, in developing countries, and with specific regard to Lesotho, it was found that teacher characteristics such as gender, class size or years of experience had no influence on students' mathematical achievement (Kanyongo et al., 2007). They found teachers' content knowledge to be the only certain influence on students' mathematical achievement. Wenglinsky (2002), in his study about the link between teachers' teaching practices and students' academic performance, reported that teaching practices are important causes of students learning and achievement and efforts to improve students' learning and achievement succeed or fail inside the classroom. According to Bransford, Brown and Cocking (1999), cognitive research has uncovered important principles for structuring teaching and learning, principles that enable students to be successful learners. Studies on the design and evaluation of learning environments (undertaken by cognitive and developmental psychologists and educators) are yielding new knowledge about the nature of learning and teaching as it takes place in a variety of settings. The impact of the new knowledge about teaching and learning on teaching practices is a shift from a teacher-centred to a leaner-centred approach to teaching. Meece, Herman and McCombs (2003) did a survey amongst 4615 US middle and high school students and provide additional empirical support for using learner-centered practices to create a positive learning environment at the classroom or school level (McCombs, 2003; McCombs \& Whisler, 1997).

Bransford et al., (1999) indicated that there are certain ways to teach students a subject such as mathematics that make it possible for the majority of students to develop a deep understanding of this important subject. To improve students' learning, mathematical education reforms have described the need for specific changes in teaching the subject. Instead of the traditional lecture method (where the teacher tells the students what they have to memorise), teachers are encouraged to introduce active learning activities that enable students to construct knowledge (Artzt, 1999; National Council of Teachers of Mathematics, 2000). The research findings of Grouws and Cebulla (2000) on improving student achievement in mathematics showed that certain teaching practices are worth careful consideration as teachers strive to improve their mathematics teaching practices.

Teaching and learning mathematics are complex processes. The effect of changing a single teaching practice on student achievement may be difficult to determine because of the simultaneous effects of both the other teaching activities that surround it and the context in which the teaching takes place. However, research studies (e.g. Hafner, 1993; Grouws \& Cebulla, 2000; Ingvarson et al., 2004) found that teaching practices that generate a high opportunity to learn are related to improved student achievement in mathematics. The literature frequently refers to a number of teaching practices that appear to be related to students' improved ability to learn. These include formal presentation, whole class teacher-guided discussion, use of group work, and use of homework 
(Hafner, 1993; Grouws \& Cebulla, 2000; Grouws, 2001; Ingvarson et al., 2004).

\section{Formal presentation}

A formal presentation (lecturing method) involves the teacher spending most of the time presenting information through lectures and/or demonstrations. The teacher takes an active role, conveying information to the students rather than just 'facilitating' learning. The information is conveyed in a brief presentation followed by opportunities for recitation and application. The teacher presents the content personally to the student rather than relying on curriculum materials or textbooks to do so. According to Reynolds and Muijs (1999) in their research on American teacher effectiveness, this method helps to improve student achievement in mathematics.

\section{Whole class teacher-guided discussion}

In this teaching method, the teacher presents the subject material in an active way by involving students in class discussion (by asking them questions). Bransford et al., (1999) identified teacher-guided whole class discussion as a teaching method that improves student achievement in mathematics. They indicated that important ideas develop when students spend a great deal of time discussing alternative strategies with each other and with the teacher. Similarly, Grouws and Cebulla (2000) claimed that whole class teacher-guided discussion is very effective in improving students' mathematical achievement. This is because it enables the students to observe many ways of examining a situation, and also helps them to understand the variety of appropriate and acceptable solutions. It could also be an effective diagnostic tool for determining the depth of student understanding and discovering their misconceptions. Teachers can identify areas of difficulty for particular students, as well as discover areas of student success or progress. This will help the teacher to make appropriate instructional decisions in helping his or her students to construct knowledge (Bransford et al., 1999).

\section{Group work}

In this teaching technique, teachers allow students to work together in groups, thus providing opportunities for them to share their methods of solution. According to Dossey et a (2002), working in groups with their peers provides students with a less threatening environment to work in, simply because they don't feel the pressure to perform in front of their peers. Group work helps to develop students' problem-solving strategies because "the fact that a group contains more knowledge than an individual means that problem solving strategies can be more powerful" (Reynolds \& Muijs, 1999, p 282). As students work in groups to solve problems and present their work to their groups, they will have opportunity to learn from each other. Collaborative group problem-solving activities improve students' higher order thinking skills. Problem-solving in the group allows the students to become more deeply involved in their learning process. It can also enhance logical reasoning, helping the students to decide what rule a situation requires or, if necessary, helps them to develop their own rules in a situation where an existing rule cannot be directly applied (Bransford et al., 1999).

Analysis of the results of 122 research studies that focused on the effects of use of peer group work on students' achievement by Marzano, Pickering and Pollock (2001), showed that use of group work improves student mathematical achievement. A similar finding was reported by many other studies (e.g. Brahier, 2000; Grouws \& Cebulla, 2000). The effectiveness of group work in improving students' achievement in mathematics has also been shown in other studies (e.g. Slavin, 1983; Dori, 1995; Abu \& Flowers, 1997; Reynolds \& Muis, 1999; Johnson \& Johnson, 2002; Sorensen, 2003). However, the use of group work does bring its own problems: for example, shared misconceptions can be reinforced by group work (Good, McCaslin \& Reys 1992), students 
might be tempted to engage in off-task social interaction (Good \& Galbraith, 1996); some students may feel that they have little or nothing to contribute to the group, and some may feel that their contributions are not valued and thus they become passive (Reynolds \& Muijs, 1999).

\section{Homework}

Homework is an instructional tool that refers to tasks assigned by teachers to students to be completed outside the regularly scheduled class. Its purpose includes providing additional practice, increasing the amount of time students are actively engaged in learning, extending time on task-developing skills, increasing understanding and developing application (Grouws, 2001). It is useful to teachers for monitoring students' learning and identifying their learning difficulties since it gives teachers feedback about their students' learning. Marking or reviewing homework also gives feedback to the students, which is a very important aspect of teaching (Bodin \& Capponi, 1996).

Cooper (1994) reported that, in the United States, homework accounted for 20 percent of the time students spent on academic tasks. However, he noted that little attention had been paid to the issue of homework in teacher education. Likewise, Eren and Henderson (2006) indicated that most of the literature on homework is theoretical; that very little empirical research has been completed on the role of homework in student achievement. Some studies documented a positive relationship between homework and student achievement. For example, Cooper (1994) indicated that homework, in addition to other effects, leads to better retention of factual knowledge, increased understanding and improved critical thinking. These are vital to improving student achievement. Betts (1997) studied the relationship between the hours of homework assigned by the teachers to the students and found it to be positively related to student achievement. Eren and Henderson (2006) reported a similar finding: they said that, relative to school factors such as class size, homework appears to have a larger and more significant impact on student achievement. Aksoy and Link (2000) found homework to have positive and significant effects on the mathematical achievement of tenth graders. The study was based on the hours the students reported spending on homework which is risky in the sense that it may give a spurious correlation since it could reflect unobserved variation in students' ability and motivation. A review of 134 studies by Marzano et al., (2001) reported a positive relationship between the use of homework and student achievement. It can be concluded that homework is positively related to student achievement, but most of the studies were carried out in environments (e.g. the United States) where parents are educated. The significant role parents play in students' homework to make it effective has been documented by many authors and researchers (e.g. OERI, 1996; Chaika, 2000; Cooper, Lindsay $\&$ Nye 2000; Cooper, 2001). The effect of homework on student achievement in an environment such as Lesotho, where most of the parents are illiterate and cannot help their children with homework, needs to be investigated. Studies in developing countries on the use of homework and student achievement shows mixed results. Fuller (1987) reported a small positive effect for Chile and Iran, but not for India and Thailand.

\section{Objective of the study}

The objective of this study is to explore correlations between teaching practices and students' mathematical achievement in Lesotho. In order to do this the following null hypotheses will be interrogated:

- There is a statistically significant relationship between student achievement in mathematics and formal presentation.

- There is a statistically significant relationship between student achievement in 
mathematics and whole class teacher guided discussion.

- There is a statistically significant relationship between student achievement in mathematics and group work.

- There is a statistically significant relationship between student achievement in mathematics and the use of homework.

\section{Research design}

The study adopted a co-relational research design. This design finds the statistical relationship between two or more variables (Lauer, 2006) - in this case between student mathematical achievement and teaching practices. Both descriptive and correlation statistics were used to analyse the data. This paper presents the descriptive statistics of data collected from the study population (a group of teachers in Lesotho), followed by a correlation analysis of the variables with students' mathematical achievements. The advantage of using a quantitative approach was twofold: firstly, it enabled the researchers to gain a general understanding of phenomena (in this case, the relationship between teaching practices and student achievement) and, secondly, it enabled the researchers to identify trends from a large population.

\section{Sample}

The study population was Form C (Grade 10) mathematics teachers in Maseru (Lesotho). The Kingdom of Lesotho has 10 districts, of which the Maseru District is the largest in terms of population size. There are a total of 54 secondary schools in the Maseru district. From these 54 schools, $40(75 \%)$ are owned by the missions, six $(10 \%)$ are owned by the government, four $(7.5 \%)$ are owned by the communities, and four $(7.5 \%)$ are owned by private individuals or organisations. The questionnaire was administered to all teachers who agreed to participate in the study (to ensure a high response rate). The questionnaire was handed out to 75 teachers. Of these teachers, 53 (six from government schools, six from community schools, 37 from mission schools and four from private schools) completed the questionnaire and included their lists of students. These lists were used to obtain the students' results from the JC results published by ECoL. The other teachers either declined to complete the questionnaire or refused to include their list of students. A proportional stratified random sample of 40 teachers based on the schools' ownership was selected from the 53 teachers for data analysis. Proportional stratified random sampling was used to eliminate selection bias. The sample of 40 teachers comprised 30 (75\%) teachers from mission schools, four (10\%) from government schools, three $(7.5 \%)$ from community schools and three $(7.5 \%)$ from private schools.

\section{Data collection: Questionnaire}

The self-report questionnaire: Mathematics Teaching Opinionate Scale (MaTOS) was used to obtain data from the teachers. MaTOS is a modified version of a self-report survey questionnaire developed by Horizon Research Incorporated (a United States company) and was used to carry out the 2000 National Survey of Mathematics Education in the entire United States and the District of Columbia as part of a larger study designed to provide up-to-date information about mathematics and science education in the United States. It was designed to identify trends in mathematics education by obtaining in-depth information from each teacher about teacher background and experience, the curriculum and instruction in a class, and the availability and use of instructional resources (Horizon Research Incorporated, 2001). This questionnaire was modified to include only those sections that elicited information relevant to the present research study. A self-report instrument was used because this has been used in large studies and teachers' self-report instruments remain the most viable means of obtaining information about the status of instructional practice (Mayer, 1999). 
To ensure that the questionnaire measures what it purports to measure and is a true reflection of the content domain, its content validity was tested by involving experts in the field of psychometrics and mathematics education, who are competent to judge whether the questionnaire reflects the content domain of the study. The reliability of the questionnaire was tested using Cronbach's alpha coefficient (Cohen, Manion \& Morrison, 2007). This was seen to be appropriate because it requires only a single test administration and provides a unique quantitative estimate of reliability for the given administration. It is also considered to be a conservative (lower bound) estimate of reliability - meaning that the true relationship is likely to be no lower than this estimate (Lapsley, 2006). The questionnaire was pre-tested with 13 Form $C$ mathematics teachers. The internal consistency reliability of the score for MaTOS for the components of teaching practices was 0.92 .

\section{Data collection: ECoL 2006 JC examination result}

The data about student achievement in mathematics was collected from the ECoL $2006 \mathrm{JC}$ examination result list. The average grade of each teacher's students was used as the student's achievement. The JC examination is a national external examination conducted by the ECoL for students at the end of their Form C. It was based on the JC syllabus and consisted of two papers (Paper $1^{1}$ and Paper $\mathrm{II}^{2}$ ), which are not appended (because permission to do so was not granted).

The content validity of the question paper was established by experts' judgment of the subject officers, specialists and the subject team members of both ECoL and the National Curriculum Development Centre (NCDC). The questions were drawn from a pool of JC examination questions set by mathematics teachers and examiners, and expert judgment was brought to bear on the questions. Before these questions were used in the examination, this expert judgment confirmed that the questions were in line with the syllabus content and were appropriate for the time allocations.

\section{Results}

Table 1 presents the teachers' report of their use of the various teaching practices. The relationship between student achievement in mathematics and teaching practices; formal presentation, whole class teacher-guided discussion, group work and homework is presented in Table 3. Table 1 shows that $95 \%$ of the teachers assigned mathematics homework at least once a week, so Table 2 was therefore included to indicate the amount of time spent on homework in a week.

\footnotetext{
$1 \quad$ Paper 1 counted for 80 marks and consisted of 30 semi-structured questions that tested students knowledge of basic mathematical skills on fractions and decimals, rounding off numbers to given decimal places, percentages, ratio, proportions and rates, properties of shapes, matrices addition and subtraction, vectors and transformations.

2 Paper II consisted of 19 short, structured application questions that required one concept per question. It counted for 100 marks and included questions on sequence, polygon, simultaneous equations, inequalities, measurement and mensuration, trigonometry, proportions and rates, interpretation of statistical data, simple probability, rotation of shapes and drawing of graphs (linear and quadratic).
} 
Table 1: Teaching practices comparison $(\mathrm{N}=40)$

\begin{tabular}{|c|c|c|c|c|c|c|}
\hline \multirow[b]{2}{*}{ Teaching practice } & \multicolumn{6}{|c|}{ Percentage } \\
\hline & $\begin{array}{l}\text { No } \\
\text { response }\end{array}$ & Never & $\begin{array}{l}\text { Rarely } \\
\text { (e.g. a few } \\
\text { times a } \\
\text { year) }\end{array}$ & $\begin{array}{l}\text { Sometimes } \\
\text { (e.g. once or } \\
\text { twice a month) }\end{array}$ & $\begin{array}{l}\text { Often (e.g. } \\
\text { once or } \\
\text { twice a } \\
\text { week) }\end{array}$ & $\begin{array}{c}\text { All or } \\
\text { almost all } \\
\text { mathematics } \\
\text { lessons }\end{array}$ \\
\hline $\begin{array}{l}\text { Introduce content } \\
\text { through formal } \\
\text { presentations }\end{array}$ & 0.0 & 5.0 & 5.0 & 20.0 & 52.5 & 17.5 \\
\hline $\begin{array}{l}\text { Engage the whole } \\
\text { class in teacher } \\
\text { guided discussions }\end{array}$ & 2.5 & 0.0 & 0.0 & 37.5 & 32.5 & 27.5 \\
\hline $\begin{array}{l}\text { Students work in } \\
\text { groups }\end{array}$ & 0.0 & 0.0 & 5.0 & 32.5 & 52.5 & 10.0 \\
\hline $\begin{array}{l}\text { Assign } \\
\text { mathematics } \\
\text { homework }\end{array}$ & 0.0 & 2.5 & 2.5 & 0 & 32.5 & 62.5 \\
\hline
\end{tabular}

Teachers' teaching practices comparison report shows that, at least once a week, $70 \%$ used formal presentations to introduce content, $60 \%$ used whole class teacher-guided discussion and $62.5 \%$ engaged students in group work.

Table 1 also shows that $62.5 \%$ of the teachers assigned mathematics homework in all or almost all mathematics lessons, while $95 \%$ did this at least once a week. Analysis of this trend was needed and the teachers were asked to indicate the amount of mathematics homework they assigned to their classes in one week. (See Table 2.) In the majority of the classes (67\%), students were assigned to at least one-hour of homework every week, and in $18 \%$ of the classes, students were assigned extensive homework of at least three hours every week.

Table 2: Amount of mathematics homework $(\mathrm{N}=40)$

\begin{tabular}{lc}
\hline \multicolumn{1}{c}{ Amount of homework in a week } & Percentage of classes \\
\hline No response & 2.5 \\
0-30 minutes & 5.0 \\
31-60 minutes & 27.5 \\
61-120 minutes & 25.0 \\
2-3 hours & 22.5 \\
More than 3 hours & 17.5 \\
\hline
\end{tabular}

Table 3 shows the relationship between the students' achievement in mathematics and specific teaching practices. The table shows that there was a very weak negative relationship between student achievement and formal presentation (teacher-centred teaching). However, there is a fairly positive relationship between students' achievements and each of the following learnercentred teaching practices: whole class teacher-guided discussion and group work. A very weak positive relationship was found between student achievement and the use of homework. The hypothesis was tested by using correlation analysis to analyse the data at 0.05 and 0.01 alpha levels. For both alpha levels the correlation between student achievement in mathematics and the different teaching practices was not statistically significant. 
Table 3: Correlations between student achievement and specific teaching practices $(\mathbf{N}=$ 40)

\begin{tabular}{lc}
\hline \multicolumn{1}{c}{ Specific teaching practices } & R \\
\hline Formal presentation & -0.015 \\
Whole class teacher-guided discussion & 0.245 \\
Group work & 0.345 \\
Homework & 0.072
\end{tabular}

\section{Discussions of the findings}

The findings of this study could not support any of the hypotheses (e.g. Betts, 1997; Bransford et al., 1999; Aksoy \& Link, 2000; Grouws \& Cebulla, 2000; Marzano et al., 2001) about the direct relationship between student achievement and different teaching practices at the $5 \%$ statistically significant level.

Analysis revealed that, among the teaching practices, formal presentation was found to have a very low insignificant-negative correlation with student achievement $(r=-0.015)$. In the light of all the critique levelled against the teacher-centred approach, this result came as no surprise.

Although student achievement in mathematics was found to positively correlate to whole class teacher-guided discussion and group work, the relationship was found to be statistically insignificant. However, these practices could have the potential of engaging the students actively in the classroom, making them active members of the learning community.

The correlation between student achievement and the use of homework - a practice widely used by the mathematics teachers in Lesotho - was found to be very low (0.072). As mentioned in the literature study, parents can play a significant role in students' homework. Further research is needed to investigate whether the parents low literacy level in Lesotho (i.e. where parents cannot help their children with their homework) is indeed a reason for this low correlation. The fact that the study found no correlation between student achievement and the use of homework is in contrast to developed countries. This result shows that developing countries face unique challenges and therefore must find their own solutions.

One of the main problems developing countries face is the lack of qualified teachers in schools (Lewin, 2000; Taylor \& Vinjevold, 1999) which, in itself, could have a hampering effect on teachers' teaching practice. Ogbonnaya (2007), in his study on the influence of teachers' background on student achievement in mathematics in Lesotho, discovered that there is a statistically significant relationship between student achievement in mathematics and the teacher's qualifications. Qualifications were measured in terms of whether the teacher had a degree, a diploma or a certificate. It was found that students whose teachers specialised in mathematics or mathematics education achieved better in mathematics than students' whose teachers did not have majors in mathematics or mathematics education. This finding was reinforced in the research undertaken by Kanyongo et al., (2007). Furthermore, in his study, Ogbonnaya discovered that $20 \%$ of grade 10 mathematics teachers do not have a degree qualification and $47.5 \%$ of the teachers do not have a major in mathematics or mathematics education. The effect of this lack of qualified and specialist mathematics teachers could account for the non-effectiveness of teaching practices in Lesotho. 


\section{Limitations of the study}

The study is purely quantitative and, as such, cannot give reasons for the nature and scope of the correlations found. The low correlations could be due to a number of factors. Further research is therefore recommended in the form of a qualitative study directed at understanding the context and the different factors involved and how these interrelate. Research is also needed to understand if and how the low levels of qualified teachers influence the correlations and if this is the reason why the findings of this study could not support any of the hypotheses.

\section{Conclusion}

Although research has found that teaching practices are critical in promoting student achievement in mathematics, this study could not confirm or reject this relationship. A positive correlation was found between student achievement in mathematics and whole class teacher-guided discussion and group work, although this correlation was statistically insignificant. Both these teaching approaches are considered to be learner-centred. The correlations, however, indicate that formal presentation as a teaching method is the most ineffective of all teaching methods. The shift towards a learner-centred teaching approach, as implemented by the Ministry of Education in Lesotho, is therefore a step in the right direction.

\section{References}

Abu, R. B. \& Flowers, J. (1997). The effects of cooperative learning methods on achievement, retention, and attitudes of home economics students in North Carolina. Journal of Vocational and Technical Education. 13 (2), 16-21.

Aksoy, T., \& Link, C. R. (2000). A panel analysis of students' mathematics achievement in the U.S in the 1990s: Does increasing the amount of time in learning activities affect math achievement? Economics of education review, 19, 126-277.

Artzt, A. (1999). Cooperative learning in mathematics teacher education. The Mathematics teacher. 92 (1), 11-17.

Betts, J. R. (1997). The role of homework in improving school quality. Unpublished manuscript. University of Calfonia San Diego.

Bodin, A. \& Copponi, B. (1996). Junior secondary school practices. In A. J. Bishop et al. (eds). International handbook of mathematics education. London: Kluwer Academic press, pp 565-614

Brahier, D. (2000). Teaching secondary and middle school mathematics. Boston: Allyn \& Bacon.

Bransford, J. D., Brown, A. L. \& Cocking, R. R. (1999). How people learn: Brain, mind, experience, and school. (ed). Retrieved July 07, 2006, from: http://newton.nap.edu/html/ howpeople1/ch7.html.

Chaika, G. (2000). Help! Homework is wrecking my home life! Education World Retrieved February 26, 2007, from

http://www.education-world.com/a_admin/admin182.shtml.

Cohen, L., Manion, L. \& Morrison, K. (2007). Research Methods in Education. Routledge: London and New York.

Cooper, H. M. (1994). The battle over homework: An administrator's guide to setting sound and 
effective polices. Thousand Oaks, CA: Corwin

Cooper, H. M. (2001). The battle over homework: Common ground for administrators, teachers, and parents. Thousand Oaks, CA: Corwin.

Cooper, H., Lindsay, J. J. \& Nye, B. (2000). Homework in the home: How student, family, and parenting-style differences relate to the homework process. Contemporary Educational Psychology, 25, 464-487.

Darling-Hammond, L. (2000). Teacher quality and student achievement: A review of state policy evidence. Education Policy analysis Archives, 8(1), 1-44.

Dori, Y. J., Yaroslavsky, O. \& Lazarowitz, R. (1995). The effects of teaching the Cell Topic using the Jigsaw Method on students' achievement and learning ability. ED387336.

Dossey, J., McCrone, S., Giordano, F. \& Weir, M. (2002). Mathematics methods and modelling for today's mathematics classroom: A contemporary approach to teaching Grades 7-12. Pacific Grove CA: Brooks/Cole.

ECOL. (2001). COSE 2000 pass list. Maseru: ECOL.

ECOL. (2005). JC 2004 pass list. Maseru: ECOL.

ECOL. (2006). JC 2005 pass list. Maseru: ECOL.

Eren, O. \& Henderson, D. J. (2006). The impact of homework on students' achievement. Retrieved February 26, 2007, from

http://people.smu.edu/oeren/document/research/eren_henderson.pdf.

Fuller, B. (1987), What School Factors Raise Achievement in the Third World? Review of Educational Research,57 (3) (Autumn, 1987), 255-292.

Good M. \& Galbraith, P. (1996). Do it this way: metacognitive strategies in collaborative mathematical problem-solving. Educational Studies in Mathematics, 30, 229-260.

Good, T. L., McCaslin, M. \& Reys, B. J. (1992). Investigating work groups t p r o m o t e problem-solving in mathematics. In D.Reynolds \& D.Muijs (eds). Th e E ffe c t i ve Teaching of Mathematics: a review of research. School leadership \& Management, 19 (3) 273-288.

Grouws, D. A. \& Cebulla, K. J. (2000). Improving students'achievement in Mathematics Part 1: Research findings ERIC/CSMEE Columbus, OH. ED423952.

Grouws, D. (2001). Homework. In L. S. Grinstein, \& S. I. Lipsey. (eds.) Encyclopedia $\quad o \quad f$ mathematics education. New York: Routledge Falmer, pp 330-331.

Hafner, A. L. (1993). Teaching method scales and mathematics-class achievement: $\quad$ wh a t works with different outcomes? American Educational Research Journal, 330 (1), 71-94.

Horizon Research Incorporated. (2001). Report of the 2000 National Survey of Science and Mathematics Education. Chapel Hill: Horizon research, Inc.

Ingvarson, L.; Beavis, A.; Bishop, A.; Peck, R. \& Elsworth, G. (2004). Investigation of Effective Mathematics teaching and Learning in Australian Secondary Schools. Australia: Australian Council for Educational Research.

Johnson, D.W. \& Johnson, R.T. (2002). Meaningful assessment: A manageable and Cooperative process. Boston: Allyn and Bacon. 
Kanyongo, G.Y., Schreiber, J.B. \& Brown, L.I. (2007). Factors affecting mathematics achievement among $6^{\text {th }}$ graders in three sub-Saharan African countries: The use of hierarchical linear models (HLM). African Journal of Research in Mathematics, Science and Technology Education, 11 (1), 37-46.

Lapsley (2006). Validity and Reliability. Retrieved: June 29, 2006 from http://www.bsu.edu/ classes/lapsley/edpsy640/validity.htm

Lauer, P. A. (2006). An educational research primer: How to understand, evaluate, and use it. San Francisco: Jossey-Bass.

Lewin, K. M. (2000). Mapping science education in developing countries. Washington, DC: World Bank, Human Development Network, Education Group.

Marzano, R. J., Pickering, D. J. \& Pollock, J. E. (2001) Classroom instruction tha works: Research-based strategies for increasing student achievement. Al ex andria, VA: association for supervision and curriculum development.

Mayer, D. P. (1999). Measuring Instructional Practice: Can Policymakers Trust Survey Data? Educational Evaluation and Policy Analysis, 21 (1), 29-25.

McCombs, B.L. (2003). Applying educational psychology knowledge base in educational reform: From research to application to policy. In: W.M. Reynolds and G.E. Miller (eds), Comprehensive Handbook of Psychology, Vol. 7. Educational Psychology. Wiley: New York, pp583-607.

McCombs, B.L. \& Whisler, S. (1997). The Learner-Centered Classroom and School, Jossey Bass, San Francisco.

Meece, J.L., Herman, P. \& McCombs, B.L. (2003). Relations of learner-centered teaching practices to adolescents' achievement goals. International Journal of Educational Research, 39 (4-5), 457-475.

Ministry of Education. (2002). Mathematics junior secondary syllabus. Maseru: Ministry of Education.

National Council of Teachers of Mathematics. (2000). Principles and standards for school mathematics. Reston, VA: National Council of Teachers of Mathematics.

OERI (1996). Let's do homework! Learning partners. Washington, DC: OERI (Office of Educational Research and Improvement).

Ogbonnaya, U. I. (2007). The influence of teacher's background, professional development and teaching practices on students' achievement in mathematics in Lesotho. Completed research dissertation. Pretoria: Unisa

Peterson, P. L. (1998). Teaching for higher-order thinking in mathematics: the challenge for the next decade. In D. D. Grouws, T. T.Cooney \& D. Jones (eds.), Perspectives on research on effective mathematics teaching (Vol. 1,). Reston, VA.: Lawrence Erlbaum Associates for the National Council of Teachers of Mathematics.

Reynolds, D. \& Muijs, D. (1999). The Effective Teaching of Mathematics: a review $\quad$ o f research. School leadership \& Management, 19 (3) 273-288.

Rice, J. K. (2003). Teacher quality: Understanding the effectiveness of Teacher Attributes. The Economic Policy institute. Retrieved November 02, 2006, from http://www.epinet.org/ content.cfm?id=1500. 
Slavin, R. E. (1983). Cooperative learning and students'achievement. New York: Longman.

Sorensen, R. (2003). Effective Teaching in High School Mathematics. Eric Digest 419.

Steen, L. A. (1989). Teaching Mathematics for Tomorrow's World. Educational Leadership, 47 (1), 18-22.

Stigler, J. W. \& Hiebert, J. (1999). The teaching gap: Best ideas from the world's teachers for improving education in the classroom. New York: Free press.

Taylor, N. \& Vinjevold, P. (Eds) (1999). Getting Learning Right. The Joint Education Trust, Wits.

Wenglinsky, H. (2002). How schools matter: The link between teacher classroom practices and student academic performance. Education Policy Analysis Archives, 10 (12). Retrieved July 12, 2006, from http://epaa.asu.edu/epaa/v10n12/ 